\title{
Article \\ T. gondii Infection in Urban and Rural Areas in the Amazon: Where Is the Risk for Toxoplasmosis?
}

\author{
Rafaela dos Anjos Pinheiro Bogoevich Morais ${ }^{1,2, *}$, Ediclei Lima do Carmo ${ }^{2}$, Wanda Silva Costa ${ }^{2}$, \\ Rodrigo Rodrigues Marinho ${ }^{2}$ and Marinete Marins Póvoa ${ }^{1,2}$ (D) \\ 1 Curso de Pós-graduação em Biologia de Agentes Infecciosos e Parasitários, Instituto de Ciências Biológicas da \\ Universidade Federal do Pará, Belém 66075-110, Brazil; povoamm@gmail.com \\ 2 Seção de Parasitologia, Instituto Evandro Chagas/SVS/MS, Ananindeua 67030-000, Brazil; \\ edicleicarmo@iec.gov.br (E.L.d.C.); wandacosta@iec.gov.br (W.S.C.); rodrigomarinho@iec.gov.br (R.R.M.) \\ * Correspondence: rafaelamorais@iec.gov.br; Tel.: +55-91-3214-2089
}

Citation: Morais, R.d.A.P.B.;

Carmo, E.L.d.; Costa, W.S.;

Marinho, R.R.; Póvoa, M.M. T. gondii Infection in Urban and Rural Areas in the Amazon: Where Is the Risk for Toxoplasmosis?. Int. J. Environ. Res. Public Health 2021, 18, 8664. https:// doi.org/10.3390/ijerph18168664

Academic Editor: Zahid Ahmad Butt

Received: 10 June 2021

Accepted: 24 July 2021

Published: 17 August 2021

Publisher's Note: MDPI stays neutral with regard to jurisdictional claims in published maps and institutional affiliations.

Copyright: (c) 2021 by the authors. Licensee MDPI, Basel, Switzerland. This article is an open access article distributed under the terms and conditions of the Creative Commons Attribution (CC BY) license (https:// creativecommons.org/licenses/by/ $4.0 /)$.

\begin{abstract}
Toxoplasmosis, an infection caused by Toxoplasma gondii, which is found worldwide, can affect human and animal health in different ways. This study aimed to estimate the infection prevalence in humans and to determine risk factors related to urban and rural areas in a municipality in the Brazilian Amazon where an outbreak had been registered. Blood samples for serological analysis were obtained, and interviews were performed to fill out an epidemiological questionnaire. A total of 1140 individuals were included, of which 70.6\% (804/1140; 95\% CI: 67.9-73.2\%) were positive for IgG anti-T. gondii antibodies. In rural areas, the prevalence was 62.6\% (95\% CI: 58.9-66.3\%), while in urban areas, it was $81.9 \%$ (95\% CI: 78.4-85.4\%). The risk of becoming infected in urban areas was 2.7 times higher $(95 \% \mathrm{CI}=2.0-3.6 \%)$ than that in rural areas. When comparing the prevalence in the age group from 1 to 10 years in both areas, the rate was $28.6 \%$ (42/147; 95\% CI: $21.3-35.9 \%)$ for rural areas and $69.4 \%(61 / 88$; CI 95\%: 59.7-79.0\%) for urban areas. Therefore, it is concluded that parasite exposure starts in the first years of life in urban areas and that disordered urban area expansion may cause an increase in exposure to the different strains of T. gondii present in the Amazon.
\end{abstract}

Keywords: Toxoplasma; prevalence; Amazon

\section{Introduction}

Toxoplasmosis, an infection caused by the protozoan Toxoplasma gondii, affects humans and other homeothermic animals. Transmission usually occurs by consumption of undercooked meat from infected animals or food/water contaminated by oocysts. On the other hand, vertical transmission can occur when a woman acquires the infection during pregnancy, causing congenital toxoplasmosis. Symptoms are normally characterized by fever, myalgia and adenomegaly, although some individuals, especially immunocompromised individuals, develop ocular involvement and splenomegaly. In congenital toxoplasmosis, central nervous system involvement can occur, resulting in ocular lesions and microcephaly [1]. In these cases, treatment is crucial, even in subclinical infections, for reducing the severity of the disease.

Infection affects one-third of the world's human population, but the prevalence varies from region to region, depending on the climate and population habits. Prevalence rates of $3.4 \%$ to $17.5 \%$ have been reported in different regions of China [2], and rates of $11.4 \%$ have been reported in the United States [3]. In Brazil, it is estimated that $60 \%$ of the population is infected [4], and in the Amazon, 66.8\% seroprevalence has been observed in indigenous people [5] and 78\% in the city of Belém, State of Pará [6].

In the Amazon, the T. gondii cycle is very complex, as conditions such as temperature and humidity, diversity of animal species, water influence and interdependence between rural/wild and urban areas favor the dispersion of oocysts and the circulation of atypical strains; this implies a risk of developing so-called "Amazonian toxoplasmosis", which 
causes serious manifestations and deaths in immunocompetent patients, as reported in Suriname and French Guiana [7].

In Brazil, outbreaks associated with the consumption of water and food contaminated with oocysts have been registered [8]. In addition, in the Brazilian Amazon, outbreaks of toxoplasmosis associated with açaí juice (fruit extracted from the forest and highly consumed in the region) intake have been recorded $[9,10]$. In 2013, an outbreak of toxoplasmosis was reported in Ponta de Pedras municipality, Pará State, Brazil, which included 90 individuals aged from 11 months to 64 years old. Infection of pregnant individuals and ocular and multivisceral toxoplasmosis were not detected. Epidemiological and spacial analysis suggested that the source of infection was açaí juice.

Depending on their type of exposure (animal contact, population density, types of food consumed, wild area contact, sanitation conditions), Amazon residents from urban and rural areas, including those from riverside communities (who live along rivers and live on fisheries and products extracted from the forest), are at risk of acquiring infection with different strains of T. gondii and developing different manifestations of toxoplasmosis. These important factors in addition to the distance to the reference health services can lead to a greater delay in diagnosis and timely treatment. Despite this, few studies have been carried out in these communities, resulting in a lack of information, which hampers the implementation of toxoplasmosis control strategies aiming at different landscapes and populations. Therefore, this study aimed to determine the prevalence and identify the risk factors for infection by T. gondii in rural and urban communities in a municipality in the Brazilian Amazon after an outbreak occurred.

\section{Materials and Methods}

\subsection{Ethical Aspects}

This study was approved by the Ethics Committee of Instituto Evandro Chagas on 26 August 2014 (CAAE 31630514.3.0000.0019/n 764.785). The sample collection and technical procedures were only initiated after adult participants provided written informed consent and parents or guardians provided written informed consent for the participating children, in accordance with Brazilian regulations.

\subsection{Study Area}

The study was carried out in the municipality of Ponta de Pedras $\left(01^{\circ} 42^{\prime} 3^{\prime \prime} \mathrm{S}\right.$ and $48^{\circ} 18^{\prime} 52^{\prime \prime}$ W), located in the Marajó Archipelago, State of Pará, Brazilian Amazon (Figure 1), with an area of $3,365,148 \mathrm{~km}^{2}$ and a territory divided into floodplain and upland areas. The estimated resident population is 25,999 inhabitants, $49 \%$ of whom live in the urban area, which is surrounded by rivers and forests, and the rest are distributed in rural areas (which include small villages on the mainland and riverside communities with residences distant from each other). Only $20 \%$ of the population has sewage and adequate sanitary treatment $[11,12]$.

\subsection{Study Design and Samples Collection}

Considering a population of 25,999 inhabitants, with a regional seroprevalence of $65 \%$ [13] and adopting a 95\% confidence level, 5\% margin of error and 10\% nonadherence to the study, a minimum sample of 364 individuals was calculated by the program Epi Info version 7.2.2.1 (Centers for Disease Control and Prevention (CDC Atlanta)).

From August 2015 to April 2018, a cross-sectional study was conducted with interviews and blood collection from 1140 individuals in health units and by active searches in residences in urban and rural areas. All participants were aged over one year and were residents of urban area neighborhoods or rural communities. Pregnant women were excluded from the study.

Approximately $5 \mathrm{~mL}$ of venous blood was collected from each individual, and serum aliquots were storage at $-20{ }^{\circ} \mathrm{C}$ until serology testing.

Sociodemographic data and epidemiological information were obtained by interview, and information collected included place of residence, age, sex, type of water consumed, 
consumption of raw/undercooked meat and soil and animal contact. Data were entered in a database with Epi Info program version 7.2.2.1.

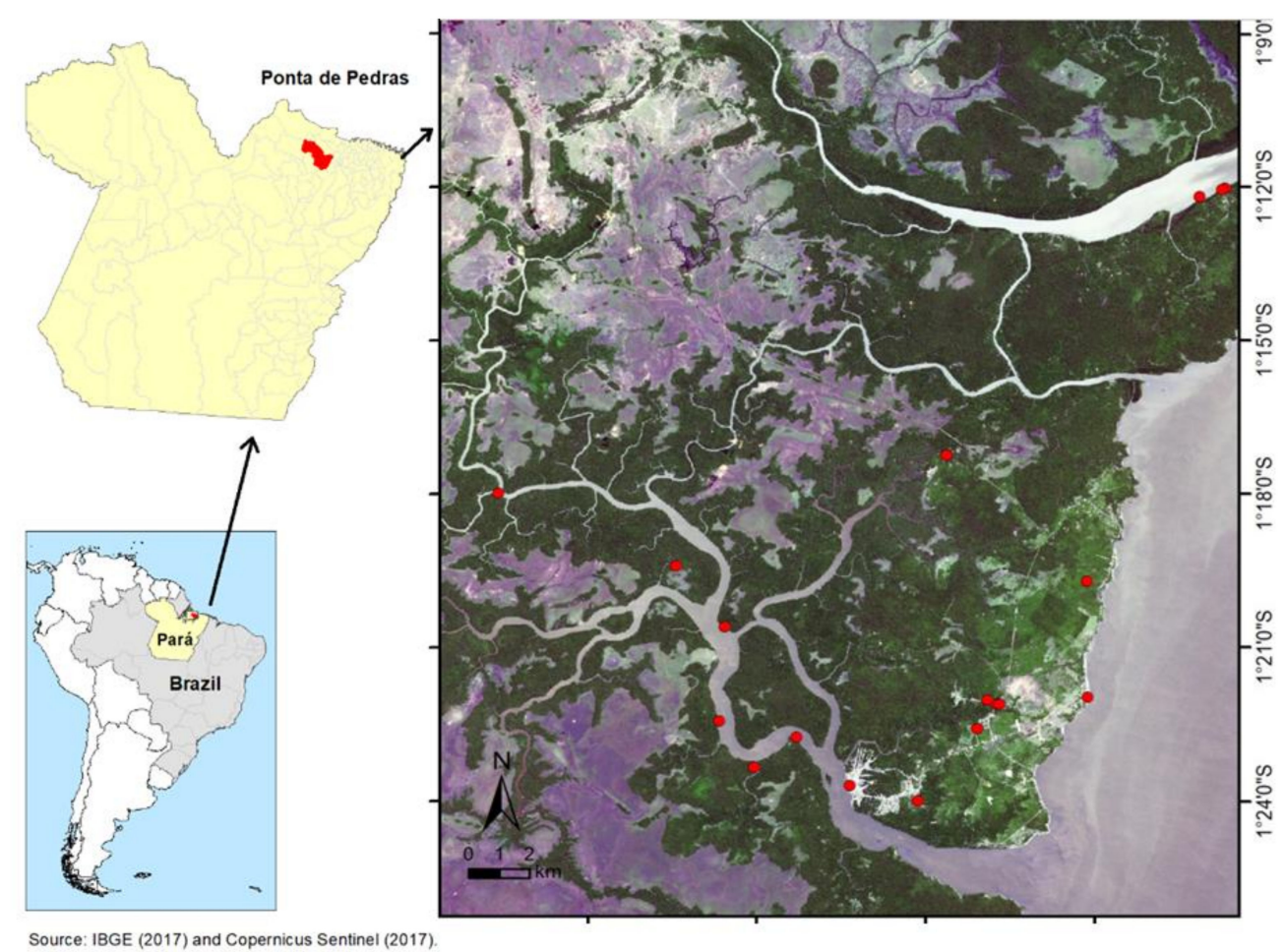

Figure 1. Map of the municipality of Ponta de Pedras, Pará State, Brazil (points in red: collection locations).

\subsection{Serological Evaluation}

Serum samples were tested for detection of $T$. gondii specific IgG by immunocapture immunoenzymatic assay (ELISA) (Symbiosis Diagnóstica Ltda., Leme, Brazil, which has a sensitivity and specificity of $99.46 \%$ and $99.16 \%$, respectively), following the procedures and cutoff calculation of the manufacturer. In addition to the positive and negative controls available in the kit, laboratory reference controls were included.

\subsection{Statistical Analysis}

Descriptive and inferential statistical methods were used. Bivariate analysis (chisquare test) was used to identify the risk factors, and variables that had a $p$-value $<0.200$ were performed by the stepwise forward method (multiple logistic regression). The factors that showed an association with the dependent variable (positive for anti-T. gondii IgG antibodies) were identified during the succession of steps. The data were analyzed with statistical programs Epi Info version 7.2.2.1.and BioEstat program version 5.3.

\section{Results}

The study included 469 (41.1\%) individuals from the urban area and 671 (58.8\%) from the rural area. The age of the population studied ranged from 1 to 89 years, with a mean age of $28.9 \pm 6.0$ (95\% CI: 26.9-30.6). Most individuals were aged 11 to 20 years (21.5\%, $245 / 1140)$, were female $(60.9 \%, 694 / 1140)$ and lived in rural areas (Table 1$)$. 
Table 1. Variables studied and seropositivity of IgG anti-T. gondii in individuals residing in the municipality of Ponta de Pedras, Pará, Brazil, from August 2015 to April 2018.

\begin{tabular}{|c|c|c|c|c|c|c|}
\hline \multirow[b]{2}{*}{ Variables } & \multicolumn{2}{|c|}{ Rural Area } & \multicolumn{2}{|c|}{ Urban Area } & \multicolumn{2}{|r|}{ Total } \\
\hline & $n$ & IgG Positive (\%) & $n$ & IgG Positive (\%) & $n$ & IgG Positive (\%) \\
\hline \multicolumn{7}{|l|}{ Sex } \\
\hline Male & 283 & $185(65.4)$ & 163 & $133(81.6)$ & 446 & $318(71.3)$ \\
\hline Female & 388 & $235(60.6)$ & 306 & $251(82.0)$ & 694 & $486(70.0)$ \\
\hline \multicolumn{7}{|l|}{ Age group } \\
\hline $1-10$ & 147 & $42(28.6)$ & 88 & $61(69.3)$ & 235 & $103(43.8)$ \\
\hline $11-20$ & 158 & $81(51.3)$ & 87 & $69(79.3)$ & 245 & $150(61.2)$ \\
\hline $21-30$ & 113 & $84(74.3)$ & 74 & $64(86.5)$ & 187 & $148(79.1)$ \\
\hline $31-40$ & 84 & $67(79.8)$ & 74 & $61(82.4)$ & 158 & $128(81.0)$ \\
\hline $41-50$ & 68 & $54(79.4)$ & 63 & $56(88.8)$ & 131 & $110(84.0)$ \\
\hline $51-60$ & 49 & $44(89.8)$ & 43 & $38(88.4)$ & 92 & $82(89.1)$ \\
\hline$>60$ & 52 & $48(92.3)$ & 40 & $35(87.5)$ & 92 & $83(90.2)$ \\
\hline \multicolumn{7}{|l|}{ Soil contact } \\
\hline Yes & 583 & $218(37.4)$ & 284 & $234(82.4)$ & 867 & $452(52.1)$ \\
\hline No & 88 & $55(62.5)$ & 185 & $150(81.1)$ & 273 & $205(75.1)$ \\
\hline \multicolumn{7}{|c|}{ Having a cat at home } \\
\hline Yes & 203 & $126(62.1)$ & 128 & $103(80.5)$ & 331 & $229(69.2)$ \\
\hline No & 468 & $294(62.8)$ & 341 & $281(82.4)$ & 809 & $575(71.1)$ \\
\hline \multicolumn{7}{|c|}{ Contact with cats } \\
\hline Yes & 486 & $318(65.4)$ & 393 & $326(82.9)$ & 879 & $644(73.3)$ \\
\hline No & 185 & $102(55.1)$ & 76 & $58(76.3)$ & 261 & $160(61.3)$ \\
\hline \multicolumn{7}{|c|}{ River water intake } \\
\hline Yes & 216 & $132(61.1)$ & 45 & $38(84.4)$ & 261 & $170(65.1)$ \\
\hline No & 455 & $288(63.3)$ & 424 & $346(81.6)$ & 879 & $634(72.1)$ \\
\hline \multicolumn{7}{|c|}{$\begin{array}{l}\text { Water treatment by boiling } \\
\text { or filtering }\end{array}$} \\
\hline Yes & 192 & $118(61.5)$ & 216 & $185(85.6)$ & 408 & $303(74.3)$ \\
\hline No & 479 & $302(63.0)$ & 253 & $199(78.6)$ & 732 & $501(68.4)$ \\
\hline \multicolumn{7}{|c|}{$\begin{array}{l}\text { Having yard with land } \\
\text { or sand }\end{array}$} \\
\hline Yes & 635 & $400(63.0)$ & 389 & $323(83.0)$ & 1024 & $723(70.6)$ \\
\hline No & 36 & $20(55.5)$ & 80 & $61(76.2)$ & 116 & $81(69.8)$ \\
\hline \multicolumn{7}{|c|}{ Açaí juice intake } \\
\hline Yes & 662 & $417(63.0)$ & 454 & $372(81.9)$ & 1116 & 789 (70.7) \\
\hline No & 9 & $3(33.3)$ & 15 & $12(80.0)$ & 24 & $15(62.5)$ \\
\hline \multicolumn{7}{|c|}{$\begin{array}{l}\text { Raw/undercooked } \\
\text { meat intake }\end{array}$} \\
\hline Yes & 177 & 115 (64.9) & 130 & $103(79.2)$ & 307 & $218(71.0)$ \\
\hline No & 494 & $305(61.7)$ & 339 & $281(82.9)$ & 833 & $586(70.3)$ \\
\hline \multicolumn{7}{|c|}{ Hunted meat intake } \\
\hline Yes & 448 & $290(64.7)$ & 189 & $152(80.4)$ & 637 & $442(69.4)$ \\
\hline No & 202 & $117(57.9)$ & 280 & $232(82.8)$ & 482 & $349(72.4)$ \\
\hline \multicolumn{7}{|c|}{ Habit of entering the forest } \\
\hline Yes & 403 & $262(65.0)$ & 176 & $147(83.5)$ & 579 & $409(70.6)$ \\
\hline No & 250 & $149(59.6)$ & 291 & $235(80.7)$ & 541 & $384(71.0)$ \\
\hline
\end{tabular}

$n$ : number.

Concerning serological analysis, 790 individuals had an immunity profile and 336 had a susceptibility profile. IgG antibodies were detected in 804 individuals, resulting in a prevalence of $70.6 \%$ (804/1140; 95\% CI: 67.9-73.2\%)

Considering only individuals from rural areas, the prevalence was $62.6 \%(95 \% \mathrm{CI}$ : $58.9-66.3 \%)$. On the other hand, in the urban area, a prevalence of $81.9 \%$ was found (95\% CI: 
78.4-85.4\%). According to the bivariate analysis, living in an urban area was a risk factor associated with seropositivity for IgG $(p<0.0001)$, where the risk of being infected was 2.7 times higher $(95 \% \mathrm{CI}=2.0-3.6 \%)$.

In the rural area, the bivariate analysis showed a statistically significant difference between seropositivity for IgG and contact with cats $(p=0.017)$ and age group $(p<0.0001)$ (Table 2).

Table 2. Bivariate analysis between the variables studied and the seropositivity of IgG anti-T. gondii in individuals residing in the rural area of the municipality of Ponta de Pedras, Pará, Brazil, from August 2015 to April 2018.

\begin{tabular}{|c|c|c|c|c|}
\hline Variables & $n$ & IgG Positive (\%) & OR (CI 95\%) & $p$-Value \\
\hline \multicolumn{5}{|l|}{ Sex } \\
\hline Male & 283 & $185(65.4)$ & $1.2(0.9-1.7)$ & 0.234 \\
\hline Female & 388 & $235(60.6)$ & & \\
\hline \multicolumn{5}{|l|}{ Age group } \\
\hline $1-10$ & 147 & $42(28.6)$ & Refer. & - \\
\hline $11-20$ & 158 & $81(51.3)$ & $2.6(1.6-4.2)$ & $<0.0001$ \\
\hline $21-30$ & 113 & $84(74.3)$ & $7.2(4.1-12.6)$ & $<0.0001$ \\
\hline $31-40$ & 84 & $67(79.8)$ & $9.8(5.2-18.7)$ & $<0.0001$ \\
\hline $41-50$ & 68 & $54(79.4)$ & $9.6(5.8-19.2)$ & $<0.0001$ \\
\hline $51-60$ & 49 & $44(89.8)$ & $22.0(8.2-59.3)$ & $<0.0001$ \\
\hline$>60$ & 52 & $48(92.3)$ & $30.0(10.2-88.4)$ & $<0.0001$ \\
\hline \multicolumn{5}{|l|}{ Soil contact } \\
\hline Yes & 583 & $218(37.4)$ & $1.0(0.6-1.6)$ & 0.921 \\
\hline No & 88 & $55(62.5)$ & & \\
\hline \multicolumn{5}{|c|}{ Having a cat at home } \\
\hline Yes & 203 & $126(62.1)$ & $0.9(0.7-1.4)$ & 0.922 \\
\hline No & 468 & $294(62.8)$ & & \\
\hline \multicolumn{5}{|c|}{ Contact with cats } \\
\hline Yes & 486 & $318(65.4)$ & $1.5(1.1-2.2)$ & 0.017 \\
\hline No & 185 & $102(55.1)$ & & \\
\hline \multicolumn{5}{|c|}{ River water intake } \\
\hline Yes & 216 & $132(61.1)$ & $0.9(0.6-1.3)$ & 0.645 \\
\hline No & 455 & $288(63.3)$ & & \\
\hline \multicolumn{5}{|c|}{ Water treatment by boiling or filtering } \\
\hline Yes & 192 & $118(61.5)$ & $0.9(0.7-1.3)$ & 0.767 \\
\hline No & 479 & $302(63.0)$ & & \\
\hline \multicolumn{5}{|c|}{ Having yard with land or sand } \\
\hline Yes & 635 & $400(63.0)$ & $1.4(0.7-2.7)$ & 0.471 \\
\hline No & 36 & $20(55.5)$ & & \\
\hline \multicolumn{5}{|c|}{ Açaí juice intake } \\
\hline Yes & 662 & $417(63.0)$ & $3.4(0.8-13.7)$ & 0.139 \\
\hline No & 9 & $3(33.3)$ & & \\
\hline \multicolumn{5}{|c|}{ Raw/undercooked meat intake } \\
\hline Yes & 177 & $115(64.9)$ & $1.1(0.8-1.6)$ & 0.502 \\
\hline No & 494 & $305(61.7)$ & & \\
\hline \multicolumn{5}{|c|}{ Hunted meat intake } \\
\hline Yes & 448 & $290(64.7)$ & $1.3(0.9-1.9)$ & 0.116 \\
\hline No & 202 & 117 (57.9) & & \\
\hline \multicolumn{5}{|c|}{ Habit of entering the forest } \\
\hline Yes & 403 & $262(65.0)$ & $1.3(0.9-1.7)$ & 0.191 \\
\hline No & 250 & $149(59.6)$ & & \\
\hline
\end{tabular}


In the multivariate analysis, the seroprevalence of $T$. gondii infection was evaluated in relation to age group, cat contact, açaí intake, hunting meat intake and the habit of entering the forest. The final logistic regression model showed an association between seropositivity for $\operatorname{IgG}$ and age group $(p<0.0001, \mathrm{OR}=6.2)$ and cat contact $(p=0.003, \mathrm{OR}=1.8)$ (Table 3$)$.

Table 3. Final model of multiple logistic regression between the studied variables and anti-T. gondii IgG seropositivity in individuals residing in rural and urban areas of the municipality of Ponta de Pedras, Pará, Brazil, from August 2015 to April 2018.

\begin{tabular}{cccc}
\hline Variable & OR & CI 95\% & $p$-Value \\
\hline Rural area & & & \\
Age $(\geq 21$ years $)$ & 6.217 & $4.33-8.92$ & $<0.001$ \\
Contact with cat & 1.799 & $1.22-2.65$ & 0.003 \\
\hline Urban area & & & 0.002 \\
Age $(\geq 21$ years $)$ & 2.118 & $1.31-3.41$ &
\end{tabular}

OR: odds ratio; $\mathrm{CI}$ : confidence interval.

In the urban area, the bivariate analysis showed a significant difference only for age group (over 20 years old) $(p<0.05)$ (Table 4). In the multivariate analysis, the seroprevalence of $T$. gondii infection was evaluated in relation to age group and water treatment by boiling or filtering. The final logistic regression model showed an association between seropositivity for IgG and age group $(p=0.002, \mathrm{OR}=2.1)$ (Table 3).

Table 4. Bivariate analysis between the studied variables and anti-T. gondii IgG seropositivity in individuals living in the urban area of the municipality of Ponta de Pedras, Pará, Brazil, from August 2015 to April 2018.

\begin{tabular}{|c|c|c|c|c|}
\hline Variables & $n$ & IgG Positive (\%) & OR (CI 95\%) & $p$-Value \\
\hline \multicolumn{5}{|l|}{ Sex } \\
\hline Male & 163 & $133(81.6)$ & $0.9(0.6-1.6)$ & 0.991 \\
\hline Female & 306 & $251(82.0)$ & & \\
\hline \multicolumn{5}{|l|}{ Age group } \\
\hline $1-10$ & 88 & $61(69.3)$ & Refer. & - \\
\hline $11-20$ & 87 & $69(79.3)$ & $1.7(0.8-3.7)$ & 0.180 \\
\hline $21-30$ & 74 & $64(86.5)$ & $2.8(1.3-6.3)$ & 0.016 \\
\hline $31-40$ & 74 & $61(82.4)$ & $2.1(0.9-4.5)$ & 0.073 \\
\hline $41-50$ & 63 & $56(88.8)$ & $3.5(1.4-8.7)$ & 0.0083 \\
\hline $51-60$ & 43 & $38(88.4)$ & $3.4(1.2-9.5)$ & 0.030 \\
\hline$>60$ & 40 & $35(87.5)$ & $3.1(1.1-8.8)$ & 0.047 \\
\hline \multicolumn{5}{|l|}{ Soil contact } \\
\hline Yes & 284 & $234(82.4)$ & $1.09(0.7-1.8)$ & 0.811 \\
\hline No & 185 & $150(81.1)$ & & \\
\hline \multicolumn{5}{|c|}{ Having a cat at home } \\
\hline Yes & 128 & $103(80.5)$ & $0.8(0.5-1.5)$ & 0.726 \\
\hline No & 341 & $281(82.4)$ & & \\
\hline \multicolumn{5}{|c|}{ Contact with cats } \\
\hline Yes & 393 & $326(82.9)$ & $1.51(0.8-2.7)$ & 0.225 \\
\hline No & 76 & $58(76.3)$ & & \\
\hline \multicolumn{5}{|c|}{ River water intake } \\
\hline Yes & 45 & $38(84.4)$ & $1.22(0.5-2.8)$ & 0.789 \\
\hline No & 424 & $346(81.6)$ & & \\
\hline \multicolumn{5}{|c|}{ Water treatment by boiling or filtering } \\
\hline Yes & 216 & $185(85.6)$ & $1.61(0.9-2.6)$ & 0.066 \\
\hline No & 253 & 199 (78.6) & & \\
\hline \multicolumn{5}{|c|}{ Having yard with land or sand } \\
\hline Yes & 389 & $323(83.0)$ & $1.5(0.8-2.7)$ & 0.202 \\
\hline No & 80 & $61(76.2)$ & & \\
\hline
\end{tabular}


Table 4. Cont.

\begin{tabular}{|c|c|c|c|c|}
\hline Variables & $n$ & IgG Positive (\%) & OR (CI 95\%) & $p$-Value \\
\hline \multicolumn{5}{|c|}{ Açaí juice intake } \\
\hline Yes & 454 & $372(81.9)$ & $1.1(0.3-4.1)$ & 0.801 \\
\hline No & 15 & $12(80.0)$ & & \\
\hline \multicolumn{5}{|c|}{ Raw/undercooked meat intake } \\
\hline Yes & 130 & $103(79.2)$ & $0.8(0.5-1.3)$ & 0.431 \\
\hline No & 339 & $281(82.9)$ & & \\
\hline \multicolumn{5}{|c|}{ Hunted meat intake } \\
\hline Yes & 189 & $152(80.4)$ & $0.8(0.5-1.4)$ & 0.583 \\
\hline No & 280 & $232(82.8)$ & & \\
\hline \multicolumn{5}{|c|}{ Habit of entering the forest } \\
\hline Yes & 176 & $147(83.5)$ & $1.2(0.7-1.9)$ & 0.531 \\
\hline No & 291 & $235(80.7)$ & & \\
\hline
\end{tabular}

n: number; OR: odds ratio; CI: confidence interval; Refer: reference.

An increase in seroprevalence was observed with age $(p<0.05)$. In the rural area, the variation ranged from $28.6 \%$ (42/147; 95\% CI: $21.3-35.9 \%)$ in children aged 1 to 10 years to $92.3 \%$ (48/52; $95 \%$ CI: $89.3-95.3 \%)$ among those over 60 years old. In the urban area, the variation ranged from $69.3 \%(61 / 88 ; 95 \%$ CI: $59.7-79.0 \%)$ to $87.5 \%(35 / 40 ; 95 \%$ CI: 37.6-50.7\%), respectively (Figure 2).

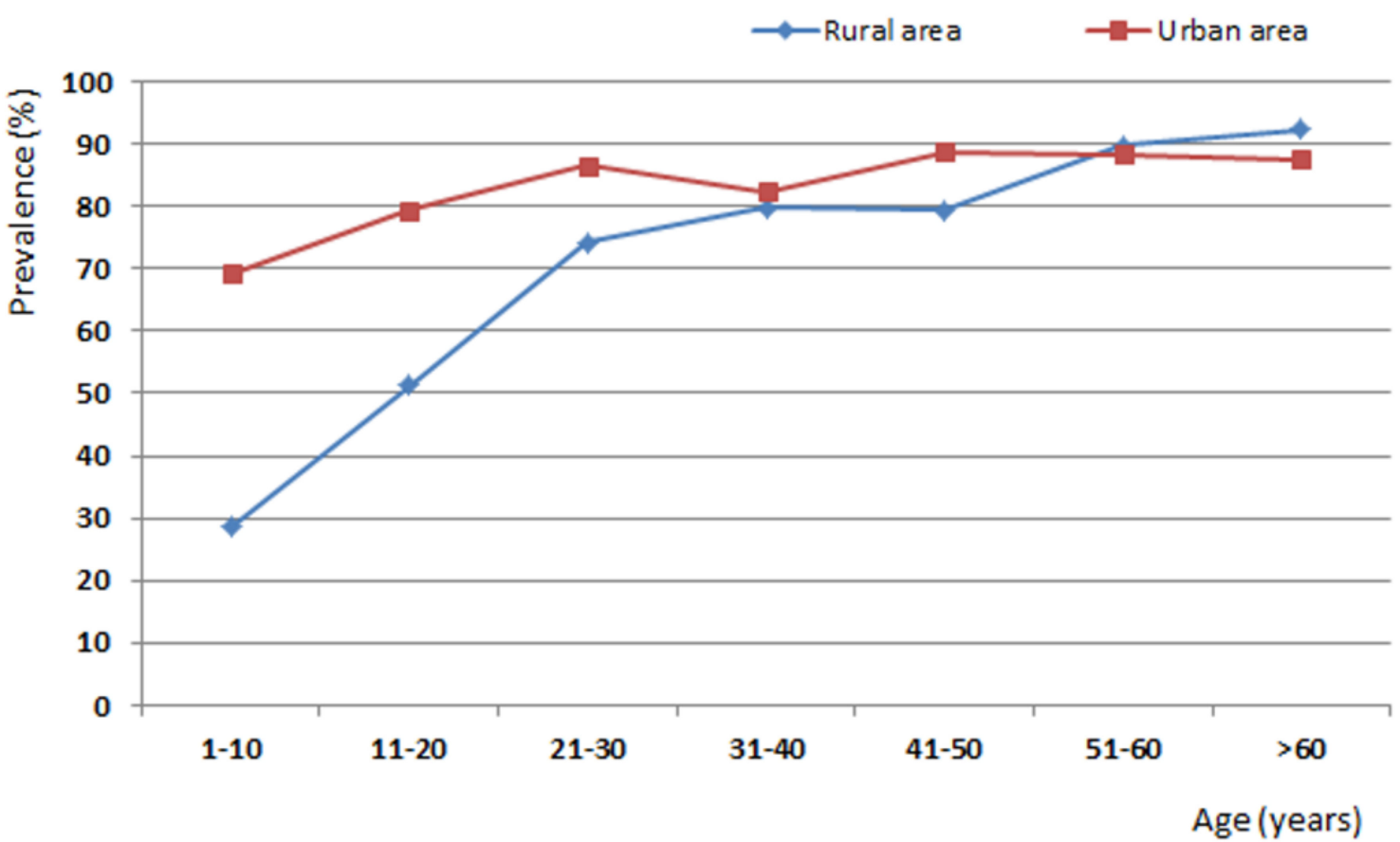

Figure 2. Anti-T. gondii IgG prevalence curve by age group in individuals living in urban and rural areas in the municipality of Ponta de Pedras, Pará, Brazil, from August 2015 to April 2018.

\section{Discussion}

The study provided information on the prevalence of $T$. gondii infection in rural and urban populations in the municipality of Ponta de Pedras, where an outbreak of toxoplasmosis occurred and which presents different landscapes and types of exposure. Thus, it was an opportunity to assess population groups and risk factors associated with infection, contributing to knowledge of the T. gondii cycle in the Amazon.

In Brazil and, more specifically, in the Amazon, the high prevalence of toxoplasmosis is a reality. Previous studies investigated specific communities or areas, such as indige- 
nous [14], riverside [15] and urban areas [6], and the present study evaluated the prevalence of toxoplasmosis and associated risk factors in individuals living in urban and rural areas, including riverside communities.

The total prevalence in the studied populations was $70.4 \%$, a rate higher than that described in countries such as Scotland, China and the United States [2,3,16] and in Brazilian cities such as Niterói (Rio de Janeiro) and Pelotas (Rio Grande do Sul) $[17,18]$ and below the rates observed in other cities in the state from Pará as Belém and Novo Repartimento [6,19].

However, when analyzed by place of residence, it was observed that the prevalence in the rural area $(63.1 \%)$ was lower than that in the urban area $(81.3 \%)$, where the risk of being infected was 2.7 times higher. This difference of greater prevalence in rural areas has often been demonstrated in Brazil [20,21] and in other countries [22,23]. On the other hand, in studies carried out in tropical countries such as Sri Lanka and Burkina Faso, a higher seroprevalence was observed among residents of urban areas, which can be explained by the conditions of poverty, overpopulation and inadequate water supply systems [24,25].

In the Amazon region, a study carried out in an indigenous community in the Alto Rio Negro basin (Amazonas) demonstrated a high frequency of detection of antibodies against $T$. gondii, which was possibly related to the process of acculturation, demographic concentration and urbanization without sanitary/health infrastructure [14]. In Ponta de Pedras, an urbanization process similar to that described above was observed and, in general, it was fast and disordered with environmental degradation, high human density, inadequate infrastructure and precarious access to treated water [26].

The prevalence observed among individuals in rural areas in this study was close to that reported for riverside communities in Lábrea, Amazonas. The authors highlighted some important points, such as persistent rains causing river floods, which make it difficult to raise animals in the home and dilute environmental contamination, reducing the likelihood of contamination of this area by oocysts [15].

In Brazil, the importance of transmission by oocysts in urban areas has already been demonstrated due to the high contamination by this infectious form, the diversity of T. gondii genotypes and the absence of actions to control stray cats [27]. In the municipality studied, there is no available information on the presence of cats, although $27.3 \%$ of residents of the urban area and $30.2 \%$ of rural areas reported having a cat, which demonstrates the presence of the animal in both areas. It is worth mentioning that it is not common in Brazilian Amazon municipalities to keep cats only inside the home and to use litter boxes, and these behaviors can contribute to environmental contamination.

The association between IgG seropositivity and cat contact was only in rural areas, where there is a low density of animals and houses that are far apart and isolated by barriers such as rivers and forests. In the urban area, the homes are close together, and there are high-density cat population groups, which have frequent access to the street, direct contact among the animals and circulation in areas such as fairs, butcher shops and markets.

Infected animals can travel greater distances, release oocysts and expose families that do not have animals to a similar risk of infection [13]. Therefore, having a cat at home was not found to be a risk factor in the rural and urban areas of the Brazilian Amazon, as demonstrated by previous studies $[13,28]$. The characteristics cited above and the conditions of temperature and humidity that favor the survival and dispersion of oocysts establish high environmental contamination and enable several routes of infection for humans and animals.

The increase in infection prevalence related to age has been demonstrated previously $[29,30]$ and is a result of duration of exposure to the parasite. Seroprevalence studies in individuals up to 20 years of age in countries such as China, Portugal and Angola showed rates between 8 and 18\% [31,32]. In the Amazon, in children up to 14 years old, a seroprevalence of $35.5 \%$ was observed in residents of the rural area of Acre and $46 \%$ in riverside communities in Amazonas [13,15]. In Ponta de Pedras, similar rates were found in children from rural areas, but in urban areas, the prevalence was much higher. 
In the analysis of the age prevalence curve, the different epidemiological profiles between urban and rural areas was prominent, mainly in the age group up to 10 years, which presented $28.6 \%$ seropositivity in rural areas and $69.3 \%$ seropositivity in the urban area. Thus, in the urban area, a high prevalence among children was observed, and no significant increase after that age was observed, in contrast to rural areas, which showed an upward curve. These facts can be explained by the different scenarios since urban areas have a high population density and large circulation of stray cats and rural areas have a low population density and small circulation of stray cats. Therefore, individuals in the urban area probably live in an environment with great contamination by oocysts and contact with the parasite from the first years of life.

Thus, it is possible that the epidemiological profiles observed in this study represent the epidemiology of $T$. gondii infection in municipalities in the Amazon region. The "tropical model" of toxoplasmosis transmission (individuals exposed to an environment highly contaminated by oocysts, with the first parasite contact occurring early in childhood) can be applied only to urban areas of the Amazon and the "Latin model" (seropositivity increases gradually with age, with the first contact with the parasite occurring mainly among young adults) to rural and wild areas [33]. Thus, urban area growth in the Amazon may increase exposure to $T$. gondii, including to atypical strains, in a reverse trend to that observed in other countries, such as France and the United States, where the prevalence has decreased in recent years [3,34].

In different locations, especially in riverside areas, access to health services is difficult, and infection by atypical strains that tend to present unusual and severe symptoms can result in a longer delay in diagnosis and treatment implementation.

\section{Conclusions}

This study showed the epidemiological profiles of $T$. gondii infection in urban and rural areas of a municipality in the Amazon, including remote areas and traditional communities. It was observed that residents of urban areas have greater exposure to the parasite starting in the first years of life, and a transmission pattern that is possibly like that observed in other tropical developing countries. Thus, it is important to establish strategies aiming at planned urban growth with a treated water supply, sanitary structure and control of stray animals. In addition, studies involving the analysis of environmental samples (soil, water, food) and the use of molecular techniques should aid in acute toxoplasmosis surveillance and understanding how environmental changes can affect the transmission of $T$. gondii in the Amazon region.

Author Contributions: Conceptualization, R.d.A.P.B.M., E.L.d.C. and M.M.P.; formal analysis, W.S.C., R.R.M. and R.d.A.P.B.M.; investigation R.d.A.P.B.M. and E.L.d.C.; writing-original draft preparation R.d.A.P.B.M.; writing-review and editing, M.M.P. and E.L.d.C. All authors have read and agreed to the published version of the manuscript.

Funding: This work was supported by the Instituto Evandro Chagas/Ministério da Saúde. This study was financed in part by the Coordenação de Aperfeiçoamento de Pessoal de Nível Superior Brasil (CAPES), Finance Code 001, PROPESP/UFPA and Conselho Nacional de Desenvolvimento Científico e Tecnológico (CNPq; Grant 302292/2017-9, Grant holder: Marinete Marins Póvoa).

Institutional Review Board Statement: This study was approved by the Ethics Committee of Instituto Evandro Chagas on 26 August 2014 (CAAE 31630514.3.0000.0019/n 764.785).

Informed Consent Statement: Informed consent was obtained from all subjects involved in the study.

Data Availability Statement: The data presented in this study are available upon reasonable request from the corresponding author.

Acknowledgments: We gratefully acknowledge all the individuals who participated in this study. We are also indebted to Secretaria Municipal de Saúde de Ponta de Pedras for logistical support during fieldwork and to José Mário Veloso Peres and Sônia Maria Nogueira Rodrigues for the technical assistance at the beginning of the study. 
Conflicts of Interest: The authors declare no conflict of interest.

\section{References}

1. Weiss, L.M.; Dubey, J.P. Toxoplasmosis: A history of clinical observations. Int. J. Parasitol. 2009, 39, 895-901. [CrossRef]

2. Pan, M.; Lyu, C.; Zhao, J.; Shen, B. Sixty years (1957-2017) of research on 255 toxoplasmosis in China-an overview. Front. Microbiol. 2017, 8, 1825. [CrossRef] [PubMed]

3. Jones, J.L.; Kruszon-Moran, D.; Elder, S.; Rivera, H.N.; Press, C.; Montoya, J.G.; McQuillan, G.M. Toxoplasma gondii Infection in the United States, 2011-2014. Am. J. Trop. Med. Hyg. 2018, 98, 551-557. [CrossRef]

4. Tuon, F.F.; Wollmann, L.C.; Pegoraro, D.; Gouveia, A.M.; Andrejow, A.P.; Schultz, A.T.; Gomes, C.J.; Novaes, O.C.; Salmória, P.A Seroprevalence of Toxoplasma gondii, cytomegalovirus and Epstein Barr virus in 578 tissue donors in Brazil. J. Infect. Public Health 2019, 12, 289-291. [CrossRef]

5. Santos, A.L.C.; Trettel, A.C.P.T.; Ribeiro, L.J.B.B.; Vasconcellos, M.L.; Zenazokenae, L.E.; Santos, M.A.; Lemos, E.R.S.; Amendoeira, M.R.R. Serological study on toxoplasmosis in the Haliti-Paresí community of the Utiariti indigenous territory, Campo Novo do Parecis, Mato Grosso, Brazil. Parasite Epidemiol. Control. 2019, 3, 1-7. [CrossRef]

6. Carmo, E.L. Aspectos Epidemiológicos da Toxoplasmose Região Metropolitana de Belém, Pará, Brasil. Ph.D. Thesis, Universidade Federal do Pará, Belém, Brazil, 2011.

7. Demar, M.; Hommel, D.; Djossou, F.; Peneau, C.; Boukhari, R.; Louvel, D.; Bourbigot, A.M.; Nasser, V.; Ajzenberg, D.; Dardé, M.L.; et al. Acute toxoplasmoses in immunocompetent patients hospitalized in an intensive care unit in French Guiana. Clin. Microbiol. Infect. 2012, 18, 221-231. [CrossRef] [PubMed]

8. Pinto-Ferreira, F.; Caldart, E.T.; Pasquali, A.K.S.; Mitsuka-Breganó, R.; Freire, R.L.; Navarro, I.T. Patterns of Transmission and Sources of Infection in Outbreaks of Human Toxoplasmosis. Emerg Infect Dis. 2019, 25, 2177-2182. [CrossRef]

9. Brasil. Ministério da Saúde. Relatório Final Sobre a Investigação do Surto de Toxoplasmose em Rondônia, Brasil; Ministério da Saúde: Brasília, Brazil, 2011; p. 2011.

10. Morais, R.A.P.B.; Freire, A.B.C.; Barbosa, D.R.B.; Silva, L.C.T.; Pinheiro, A.F.; Costa, S.S.; Ramos, F.L.P.; Bichara, C.N.C.; Lima, L.J.B.; Silva, A.V.; et al. Surto de toxoplasmose aguda no Município de Ponta de Pedras, Arquipélago do Marajó, Estado do Pará, Brasil: Características clínicas, laboratoriais e epidemiológicas. Rev. Pan-Amaz. Saude 2016, 7, 143-152. [CrossRef]

11. Instituto Brasileiro de Geografia e Estatística. Available online: https://cidades.ibge.gov.br/brasil/pa/ponta-de-pedras/ panorama (accessed on 13 March 2021).

12. Lima, V.M.; Costa, S.M.F.; Ribeiro, H. Uma contribuição da metodologia peir para o estudo de uma pequena cidade na Amazônia: Ponta de Pedras, Pará. Saude Soc. 2017, 26, 1071-1086. [CrossRef]

13. Ferreira, M.U.; Hiramoto, R.M.; Aureliano, D.P.; Silva-Nunes, M.; Silva, N.S.; Malafronte, R.S.; Muniz, P.T. A communitybased survey of human toxoplasmosis in rural Amazonia: Seroprevalence, seroconversion rate, and associated risk factors. Am. J. Trop. Med. Hyg. 2009, 81, 171-176. [CrossRef]

14. Bóia, M.N.; Carvalho-Costa, F.A.; Sodré, F.C.; Pinto, G.M.T.; Amendoeira, M.R.R. Seroprevalence of Toxoplasma gondii infection among indian people living in Iauareté, São Gabriel da Cachoeira, Amazonas, Brazil. Rev. Inst. Med. Trop. Sao Paulo 2008, 50, 17-20. [CrossRef] [PubMed]

15. Vitaliano, S.N.; Mendonça, G.M.; Sandres, F.A.M.; Camargo, J.S.A.A.; Tarso, P.; Basano, S.A.; Silva, J.C.D.; Souza, V.K.G.; Cartonilho, G.; Almeida, A.T.S.; et al. Epidemiological aspects of Toxoplasma gondii infection in riverside communities in the Southern Brazilian Amazon. Rev. Soc. Bras. Med. Trop. 2015, 48, 301-306. [CrossRef] [PubMed]

16. Burrells, A.; Opsteegh, M.; Pollock, K.G.; Alexander, C.L.; Chatterton, J.; Evans, R.; Walker, R.; McKenzie, C.A.; Hill, D.; Innes, E.A.; et al. The prevalence and genotypic analysis of Toxoplasma gondii from individuals in Scotland, 2006-2012. Parasit. Vectors 2016, 9, 324. [CrossRef] [PubMed]

17. Moura, F.L.; Amendoeira, M.R.; Bastos, O.M.; Mattos, D.P.; Fonseca, A.B.; Nicolau, J.L.; Neves, L.B.; Millar, P.R. Prevalence and risk factors for Toxoplasma gondii infection among pregnant and postpartum women attended at public healthcare facilities in the City of Niterói, State of Rio de Janeiro, Brazil. Rev. Soc. Bras. Med. Trop. 2013, 46, 200-207. [CrossRef]

18. Araújo, A.C.; Vilela, M.M.; Sena-Lopes, A.; Farias, N.A.R.; Faria, L.M.J.; Avila, L.F.C.; Berne, M.E.A.; Borsuk, S. Seroprevalence of Toxoplasma gondii and Toxocara canis in a human rural population of Southern Rio Grande do Sul. Rev. Inst. Med. Trop. S. Paulo. 2018, 60, e28. [CrossRef] [PubMed]

19. Carmo, E.L.; Morais, R.A.P.B.; Oliveira, A.S.; Figueredo, J.E.; Figueredo, M.C.; Silva, A.V.; Bichara, C.N.C.; Póvoa, M.M. Soroepidemiologia da infecção pelo Toxoplasma gondii no Município de Novo Repartimento, Estado do Pará, Brasil. Rev. Pan-Amaz. Saude 2016, 7, 79-87. [CrossRef]

20. Dias, R.C.F.; Lopes-Mori, F.M.R.; Mitsuka-Breganó, R.; Dias, R.A.F.; Tokano, D.V.; Reiche, E.M.V.; Freire, R.L.; Navarro, I.T. Factors associated to infection by Toxoplasma gondii in pregnant women attended in Basic Health Units in the city of Rolândia, Paraná, Brazil. Rev. Soc. Bras. Med. Trop. 2011, 53, 185-191. [CrossRef]

21. Antinarelli, L.; Silva, M.R.; Guimarães, R.; Terror, M.S.; Lima, P.E.; Ishii, J.; Muniz, P.F.; Coimbra, E.S. Rural residence remains a risk factor for Toxoplasma infection among pregnant women in a highly urbanized Brazilian area: A robust cross-sectional study. Trans. R. Soc. Trop. Med. Hyg. 2020, traa153. [CrossRef]

22. Taylor, M.R.; Lennon, B.; Holland, C.V.; Cafferkey, M. Community study of toxoplasma antibodies in urban and rural schoolchildren aged 4 to 18 years. Arch. Dis. Child. 1997, 77, 406-409. [CrossRef] 
23. Muñoz-Zanzi, C.; Williams-Nguyen, J.; Belongia, E.A. A sero-survey of toxoplasmosis in farm and non-farm children from Wisconsin, United States, 1997-1999. BMC Public Health 2013, 13, 837. [CrossRef] [PubMed]

24. Bamba, S.; Cissé, M.; Sangaré, I.; Zida, A.; Ouattara, S.; Guiguemdé, R.T. Seroprevalence and risk factors of Toxoplasma gondii infection in pregnant women from Bobo Dioulasso, Burkina Faso. BMC Infect. Dis. 2017, 17, 482-487. [CrossRef]

25. Iddawela, D.; Vithana, S.; Ratnayake, C. Seroprevalence of toxoplasmosis and risk factors of Toxoplasma gondii infection among pregnant women in Sri Lanka: A cross sectional study. BMC Public Health 2017, 17, 930-935. [CrossRef]

26. Huffner, J.G.P.; Oliveira, A.R.F. Crescimento urbano desordenado no município de Ponta de Pedras na Ilha do Marajó: Um estudo de caso do bairro do Carnapijó. InterEspaço: Revista de Geografia e interdisciplinaridade 2018, 3, 159-181. [CrossRef]

27. Shapiro, K.; Bahia-Oliveira, L.; Dixon, B.; Dumètre, A.; Wit, L.A.; VanWormer, E.; Villena, I. Environmental transmission of Toxoplasma gondii: Oocysts in water, soil and food. Food Waterborne Parasitol. 2019, 15, e00049. [CrossRef] [PubMed]

28. Cavalcante, G.T.; Aguilar, D.M.; Camargo, L.M.; Labruna, M.B.; de Andrade, H.F.; Meireles, L.R.; Dubey, J.P.; Thulliez, P.; Dias, R.A.; Gennari, S.M. Seroprevalence of Toxoplasma gondii antibodies in humans from rural Western Amazon, Brazil. J. Parasitol. 2006, 92, 647-649. [CrossRef] [PubMed]

29. Muñoz-Zanzi, C.; Campbell, C. Seroepidemiology of toxoplasmosis in rural and urban communities from Los Rios Region, Chile. Infect. Ecol. Epidemiol. 2016, 6, 1-9. [CrossRef]

30. Avelar, M.V.; Martinez, V.O.; Moura, D.L.; Barros, I.A.; Primo, A.A.S.; Duarte, A.O.; Soares, N.M.; Lima, F.W.M. Association between seroprevalence of IgG anti-Toxoplasma gondii and risk factors for infection among pregnant women in Climério de Oliveira Maternity, Salvador, Bahia, Brazil. Rev. Inst. Med. Trop. S. Paulo 2017, 59, e90. [CrossRef]

31. Lobo, M.L.; Patrocinio, G.; Sevivas, T.; Sousa, B.; Matos, O. Portugal and Angola: Similarities and differences in Toxoplasma gondii seroprevalence and risk factors in pregnant women. Epidemiol. Infect. 2017, 145, 30-40. [CrossRef] [PubMed]

32. Cong, W.; Elsheikha, H.M.; Zhou, N.; Peng, P.; Qin, S.Y.; Meng, Q.F.; Qian, A.D. Prevalence of antibodies against Toxoplasma gondii in pets and their owners in Shandong province, Eastern China. BMC Infect. Dis. 2018, 18, 430. [CrossRef] [PubMed]

33. Carme 2001. Exposition a Toxoplasma gondii et risque de foetopathie toxoplasmique. Med. Trop. 2001, 61, 6.

34. Guigue, N.; Léon, L.; Hamane, S.; Gits-Muselli, M.; Le Strat, Y.; Alanio, A.; Bretagne, S. Continuous Decline of Toxoplasma gondii Seroprevalence in Hospital: A 1997-2014 Longitudinal Study in Paris, France. Front. Microbiol. 2018, 9, 2369. [CrossRef] [PubMed] 